những bệnh nhân đã được phẫu thuật sửa chữa lại cơ thắt trong. Nghiên cứu của Hassink và cộng sự cho những trẻ trên 18 tuổi nhận thấy rằng những trẻ bị són phân sẽ rất khó khăn trong giai đoạn học tiểu học $(86 \%)$, giai đoạn học trung học có tới $50 \%$ trẻ gặp khó khăn trong việc học tập và tham gia các hoạt động xã hội như bới, thể dục, thể thao, cắm trại... 50\% trẻ phải nghỉ học ở giai đoạn học tiểu học. Nghiên cứu cũng chỉ ra có tới $40 \%$ trẻ có vấn đề khi tạo lập mối quan hệ bạn bè khi đến 13 tuổi, chỉ có 5\% trẻ từ 13 - 18 tuổi muốn có thêm nhiêuu bạn.

\section{KẾT LUẬN}

Phẫu thuật đường sau trực tràng một thì điều trị dị tật hậu môn tiền đình là một phẫu thuật an toàn, giúp giảm số lần nhập viện cũng như giảm gánh nặng cho bệnh nhi cũng như gia đình. Những biến chứng sau mổ có thể chấp nhận được và có thể được cải thiện sau quá trình chắm sóc. Tình trạng són phân và táo bón có thể đạt kết quả tốt ở những trẻ được chỉ định mổ với nhóm tuổi dưới 3 tháng tuổi.

\section{TÀI LIÊU THAM KHẢO}

1. Bộ môn Ngoại Nhi Đại học Y Dược TP Hồ Chí
Minh. Ngoai nhi lâm sàng. Nhà xuất bản Y hocc. 2018.

2. Ajay Narayan Gangopadhyay, Vaibhav Pandey. Anorectal malformations. J Indian Assoc Pediatr Surg 2015;20(1):10-15.

3. DeVries PA, Peña A. Posterior sagittal anorectoplasty. J Pediatr Surg. 1982;17(5):638-643.

4. Peña A. BA. Surgical treatment of colorectal problems in children. Springer publisher; 2015.

5. Nguyến Thanh Liêm, Trấn Anh Quỳnh, Phăm Duy Hiển. Điều trị dị tật hậu môn trực tràng bẳng phâu thuật một thì quà đưởng sau trực tràng giứ nguyên cơ thắt ở sơ sinh. Thông tin y dược. 2006; Chuyên đề phẫu thuật nhi:2-4.

6. Nguyen Thanh Liem, Tran Anh Quynh. One stage operation through modified posterior sagittal approach preserving the sphincter intact for anal agenesis with rectovestibular fistula. Journal of Pediatric Surgery. 2015;50:634-637.

7. Stephens F, Smith ED. Classification, identification, and assessment of surgical treatment of anorectal anomalies. Pediatric surgery international. 1986;1(4):200-205.

8. Nguyến Thanh Liếm, Bùi Đức Hậu. Đánh giá kêt quả lâu dài điều trị dị tật hậu mồn trực tràng loại cao và trung gian bằng kĩ thuật tạo hình hậu mồn trực tràng đướng sau trực tràng cải tiến. Tạp chí y học thực hành. 2001;391:273 - 276.

9. Trân Anh Quỳnh. Nghiên cứu ứng dùng và đánh giá kết quả điéu tri dị tât hâu môn trực tràng loai cao và ổ nhớp bằng phẩu thuâat nội soi. Luận án tiến sỹ y học. 2017; Học viện quấn y.

\title{
ĐÎ̂̀U TRỊ HộI CHỨNG QUÁ KÍCH BUỒNG TRỨNG NẶNG Ở BỆNH NHÂN THỤ TINH ỐNG NGHIỆM TẠI BỆNH VIỆN PHỤ SẢN HẢI PHÒNG
}

\section{TÓM TẮT}

Mục tiêu: Đánh giá kết quả điều trị hội chứng quá kích buồng trứng nặng ở bệnh nhân thụ tinh ống nghiệm tại Bệnh viện Phụ Sản Hải Phòng. Đoối tượng và phướng pháp nghiên cứu: 80 bệnh nhân quá kích buồng trứng mức độ nặng sau điểu trị thụ tinh ống nghiệm điều trị tại trung tâm hố trợ sinh sản Bệnh viện phụ sản Hải Phòng từ 01/01/2017$31 / 12 / 2019$. Kết quả: Tuổi trung bình của bệnh nhân trong nhóm nghiên cứu là 28,62 $\pm 3,49$ năm, lý do vào viện chủ yếu có triệu chứng đau bụng là $88,8 \%$, tỷ lệ bệnh nhân buồn nôn và nôn là $83,8 \%$. Bệnh nhân hạ albumin huyết thanh khi nhập viện chiếm $82,5 \%$ trong đó thấp nhất là $21,0 \mathrm{~g} / \mathrm{l}$. Tỵ lệ bệnh nhân cô đặc máu là mức độ nặng (hematocrit > 50\%) là $13,8 \%$. Điều trị nội khoa đơn thuần chiếm $30 \%$ và

\footnotetext{
${ }^{1}$ Đại học Y Hải Phòng

¿Đại học Y Hà Nội

Chịu trách nhiệm chính: Phạm Thanh Nhàn

Email: thanhnhan581991@gmail.com

Ngày nhận bài: 13.9.2021

Ngày phản biện khoa học: 3.11.2021

Ngày duyệt bài: 15.11.2021
}

\section{Phạm Thanh Nhàn ${ }^{1}$, Hồ Sỹ Hùng ${ }^{2}$}

$70 \%$ phải điều trị kết hợp cả nội khoa và chọc dịch ổ bụng. Có $53,8 \%$ bệnh nhân khỏi hoàn toàn khi xuất viện, $46,2 \%$ bệnh nhân ra viện thuyên giảm bệnh điêu trị theo đơn, không có trường hợp tử vong.

Tư khóa: quá kích buồng trứng nặng, albumin huyết thanh, chọc dịch ổ bụng.

\section{SUMMARY \\ TREATMENT OF SEVERE OVARIAN \\ HYPERSTIMULATION SYDROME IN IN \\ VITRO FERTILIZATION PATIENTS AT \\ HAIPHONG OBSTETRICS AND GYNECOLOGY HOSPITAL}

Objectives: To evaluate the treatment results of severe ovarian hyperstimulation syndrome in in vitro fertilization patients at Hai Phong Obstetrics and Gynecology Hospital. Research subjects and methods: Medical records of 80 patients. in vitro fertilization with severe ovarian hyperstimulation was treated at the fertility center - Hai Phong Obstetrics and Gynecology Hospital from January 1, 2017 to December 31, 2019. Results: The average age of patients in the study group was $28.62 \pm 3.49$ years, the main reason for admission to the hospital with abdominal pain was $88.8 \%$, the rate of patients with 
nausea and vomiting was $83 ., 8 \%$. Patients with hypoalbuminemia on admission accounted for $82.5 \%$ of which the lowest was $21.0 \mathrm{~g} / \mathrm{l}$. The proportion of patients with hemoconcentration as severe (hematocrit > 50\%) was $13.8 \%$. Medical treatment alone accounted for $30 \%$ and $70 \%$ had to be treated in combination with both medical and peritoneal puncture. There were $53.8 \%$ of patients completely cured upon discharge, $46.2 \%$ of patients discharged from hospital were in remission for prescription treatment, and there were no deaths.

Key words: severe ovarian hyperstimulation, serum albumin, peritoneal puncture.

\section{I. ĐĂT VẤN ĐỀ}

Phương pháp điều trị vô sinh thụ tinh ống nghiệm ngày càng phát triển, với quy trình cơ bản là kích thích buông trứng, mục đích để đạt được số lượng nang noãn và số phôi phù hợp nhẳm tăng tỷ lệ có thai. Tuy nhiên kích thích buồng trứng và trưởng thành noãn cso thể gây ra hội chứng quá kích buồng trứng. Đây là tình trạng đáp ứng quá mức của buồng trứng gây ra tình trạng tăng tính thấm thành mạch, xuất hiện đầu tiển từ mạch máu buồng trứng đến các cơ quan. Với mong muốn góp phần làm rõ thêm cách xử trí của quá kích buồng trứng, chúng tôi tiến hành đề tài nghiên cứu với mục tiêu: "Đánh giá kết quả điều trị hội chứng quá kích buồng trứng nặng ở bệnh nhẩn thụ tinh ống nghiệm tại Bệnh viện Phụ Sản Hải Phòng".

\section{II. ĐỐI TƯỢNG VÀ PHƯƠNG PHÁP NGHIÊN CỨU}

2.1. Đối tượng nghiên cứu. Gồm 80 bệnh nhân quá kích buồng trứng mức độ nặng sau điều tri thụ tinh ông nghiệm điều trị tại trung tâm hỗ trợ sinh sản -Bệnh viện phụ sản Hải Phòng từ 01/01/2017 - 31/12/2019 có hồ sơ lưu trữ tại phòng kế hoạch tổng hợp, thỏa mãn các tiêu chuẩn sau:

\section{Tiêu chuẩn lựa chọn}

- Bệnh nhân được điều trị thụ tinh ống nghiệm chuyển phôi tươi.

- Bệnh nhân được chẩn đoán trên lâm sàng

III. KẾT QUẢ NGHIÊN CỨU

\section{1. Đăc điểm của đối tượng nghiên cứu}

\section{Bảng 3.1. Đặc điểm của đổî tượng nghiên cứu}

\begin{tabular}{|c|c|c|c|c|c|}
\hline \multicolumn{2}{|c|}{ Đăc điếm } & n & Tỷ lệ \% & $X \pm S D$ & Min-Max \\
\hline \multirow{4}{*}{ Nhóm tuổi } & $<25$ & 13 & 16,2 & \multirow{4}{*}{$28,62 \pm 3,49$} & \multirow{4}{*}{$20-36$} \\
\hline & $25-29$ & 47 & 58,8 & & \\
\hline & $30-34$ & 15 & 18,8 & & \\
\hline & $35-39$ & 5 & 6,2 & & \\
\hline \multirow{2}{*}{ Thời gian vô sinh } & $<5$ & 61 & 76,2 & \multirow{3}{*}{$4,45 \pm 1,56$} & \multirow{3}{*}{$1-7$} \\
\hline & $\geq 5$ & 19 & 23,8 & & \\
\hline \multicolumn{2}{|c|}{ Tông } & 80 & 100 & & \\
\hline
\end{tabular}

Nhận xét: Nhóm tuổi phổ biến nhất là từ 25 đến 29 tuổi với 58,8\%, tiếp đến là nhóm 30-34 và cận lâm sàng quá kích buồng trứng mức độ nặng.

- Các bệnh án phải có đủ thông tin cần thiết phục vụ cho nghiên cứu.

\section{Tiêu chuẩn loại trừ}

- Bệnh nhân được điều trị thụ tinh ống nghiệm chuyển phôi đông lạnh.

Bệnh nhân chỉ kích thích buồng trứng để hiến tặng noãn.

- Bệnh nhân đã bị phẫu thuật ở buồng trứng.

- Những bênh án không đủ thổng tin nghiên cứu.

2.2. Thiết kế nghiên cứu. Nghiên cứu hồi cứu mô tả.

2.3. Cỡ mẫu nghiên cứu. Đây là nghiên cứu hồi cứu mô tả, cõ̃ mẫu của nghiên cứu được tính theo công thức ước lượng một tỷ lệ:

$\mathbf{n}=$

$$
Z_{1-\frac{\alpha}{2}}^{2} \frac{p(1-p)}{(\varepsilon \cdot p)^{2}}
$$

Trong đó: $\mathrm{p}=0,833$, là tỉ lệ điều trị khỏi quá kích buồng trứng nặng tại Bệnh viện Phụ sản Trung Ương năm 2013 theo nghiên cứu của Nguyễn Thị Phương Lan ${ }^{1}$

a: 0,05 tương ứng độ tin cậy 95\%.

$\varepsilon: 0,1$. Khoảng sai lệch mong muốn.

$Z^{2}{ }_{1-a / 2:}: 1,96$. Giá trị thu được từ bảng $Z$ ứng với giá trị $a=0,05$.

Từ đó tính được $n=77$. Cõ̃ mẫu thực tế trong nghiên cứu là 80 bệnh nhân.

2.4. Biến số nghiên cứu. Tuổi, thời gian vô sinh, phân loại vô sinh (nguyên phát, thứ phát). Triệu chứng cơ năng (đau bụng, buồn nôn, khó thở, thiểu niệu), chỉ số sinh hóa, huyết học khi nhập viện: albumin, protein, bạch cầu. Tình trạng cô đặc máu (hematocrit), phương pháp điều trị quá kích buồng trứng (nội khoa, nội khoa + chọc dịch ổ bụng), kết quả điều trị khi xuất viện

2.5. Đạo đức nghiên cứu. Nghiên cứu hồi cứu không can thiệp trên bệnh nhân, thông tin của bệnh nhân được đảm bảo giữ kín bí mật và trung thực theo các quy định về nghiên cứu y sinh. tuổi với 18,8\%, nhóm <25 tuổi có tỷ lệ là 16,2\%, thấp nhất là nhóm 35 đến 39 tuổi với 6,2\%. Tuối 
trung bình của bệnh nhân trong nhóm nghiên cứu là 28,62 $\pm 3,49$ năm, bệnh nhân ít tuổi nhất là 20 tuổi, lớn nhất là 36 tuổi.

Thời gian vô sinh phổ biến là nhóm bệnh nhân vô sinh < 5 năm chiếm $76,2 \%$, có $23,8 \%$ bệnh nhân vô sinh $\geq 5$ năm. Thời gian vô sinh trung bình là $4,45 \pm 1,56$ năm, ngắn nhất là 1 năm, dài nhất là 7 năm.

\subsection{Triệu chứng cơ năng và một số chỉ số sinh hóa, huyết học}

\section{Bảng 3.2 Triêuu chứng cơ năng và một số chỉ số sinh hóa, huyêt học}

\begin{tabular}{|c|c|c|c|c|c|}
\hline \multicolumn{2}{|c|}{ Triệu chứng và chỉ số } & $\mathbf{n}$ & Tý lệ \% & $X \pm S D$ & (Min-Max) \\
\hline \multirow{4}{*}{$\begin{array}{c}\text { Triệu chứng cơ } \\
\text { năng }\end{array}$} & Đau bụng & 71 & 88,8 & & \\
\hline & Buồn nôn, nôn & 67 & 83,8 & & \\
\hline & Khó thơ & 60 & 75,0 & & \\
\hline & Thiếu niệu & 47 & 58,8 & & \\
\hline \multirow{2}{*}{$\begin{array}{l}\text { Albumin } \\
\text { (g/lit) }\end{array}$} & $<35$ & 66 & $\frac{82,5}{175}$ & \multirow{2}{*}{$31,5 \pm 4,5$} & \multirow{2}{*}{$21,0-42,0$} \\
\hline & $\geq 35$ & 14 & 17,5 & & \\
\hline \multirow{2}{*}{$\begin{array}{c}\text { Protein } \\
\text { (g/lit) }\end{array}$} & $<65$ & 51 & 63,8 & \multirow{2}{*}{$63,70 \pm 4,8$} & \multirow{2}{*}{$51.00-79.2$} \\
\hline & $\begin{array}{l}\geq 65 \\
15-25\end{array}$ & 29 & $\begin{array}{l}38,2 \\
862\end{array}$ & & \\
\hline $\begin{array}{l}\text { Số lượng bạch } \\
\text { câu }(G / I)\end{array}$ & $\begin{array}{l}15-25 \\
>25\end{array}$ & $\begin{array}{l}69 \\
11\end{array}$ & $\begin{array}{l}86,2 \\
13,8\end{array}$ & $19,17 \pm 3,78$ & $15,07-30,2$ \\
\hline \multirow{3}{*}{ НСТ(\%) } & $41,0 \%-44,9 \%$ & 39 & 48,8 & \multirow{3}{*}{$43,23 \pm 4,5$} & \multirow{3}{*}{$42,23-55,04$} \\
\hline & $45,0 \%-50,0 \%$ & 30 & 37,5 & & \\
\hline & $>50,0 \%$ & 11 & 13,8 & & \\
\hline
\end{tabular}

Nhận xét: Tỷ lệ bệnh nhân có triệu chứng đau bụng là $88,8 \%$, tỷ lệ bệnh nhân buồn nônnôn là $83,8 \%$, tỷ lệ bệnh nhân có khó thở là $75,0 \%$, tỷ lệ bệnh nhân có thiệu niệu là $41,2 \%$.

Bệnh nhân có hạ albumin huyết thanh khi nhập viện chiếm $82,5 \%$, trong đó thấp nhất là $21,0 \mathrm{~g} / \mathrm{l}$. Nồng độ albumin huyêt thanh trung bình khi nhập viện là $31,5 \pm 4,5 \mathrm{~g} /$ lit. Bệnh nhân hạ protein toàn phần huyết thanh khi nhập viện chiếm $63,8 \%$, trong đó thấp nhất là $51,0 \mathrm{~g} / \mathrm{l}$. Nồng độ protein huyết thanh trung bình khi nhập viện là $63,70 \pm 4,8 \mathrm{~g} / \mathrm{l}$. Bệnh nhân có số lượng bạch câuu $>25 \mathrm{G} / \mathrm{l}$ chiếm $13,8 \%$, cao nhất là $30,2 \mathrm{G} / \mathrm{l}$. Số lượng bạch cầu trung bình là 19,17 $\pm 3,78 \mathrm{G} / \mathrm{l}$.

Tỷ lệ bệnh nhân cô đặc máu mức độ nặng (hematocrit > 50\%) là 13,8\%.

\subsection{Phương pháp điêu trị và kết quả khi xuất viện}

Bảng 3.3 Phương pháp điều trị và kêt quả khi bệnh nhân xuât viện

\begin{tabular}{|c|c|c|c|}
\hline \multicolumn{2}{|c|}{ Điều trị } & $\begin{array}{c}\text { Số } \\
\text { lượng }\end{array}$ & $\begin{array}{c}\text { Tỷ lệ } \\
\mathbf{\%}\end{array}$ \\
\hline $\begin{array}{c}\text { Phương } \\
\text { pháp }\end{array}$ & Nội khoa đớn thuần & 24 & 30,0 \\
\cline { 2 - 4 } & Nội khoa + chọc dịch & 56 & 70,0 \\
\hline \multirow{2}{*}{ Kết quả } & Khỏi hoàn toàn & 43 & 53,8 \\
\cline { 2 - 4 } & Thuyên giảm & 37 & 46,2 \\
\hline \multicolumn{2}{|c|}{ Tống } & $\mathbf{8 0}$ & $\mathbf{1 0 0}$ \\
\hline
\end{tabular}

Nhận xét: Có 24 bệnh nhân chỉ điều trị nội khoa đơn thuần chiếm $30 \%$. Có 56 bênh nhân trong nhóm nghiên cứu chiếm $70 \%$ phải điều trị kết hợp cả nội khoa và chọc dịch.

Có $53,8 \%$ bệnh nhân khỏi hoàn toàn khi xuất viện, 46,2\% bệnh nhân ra viện thuyên giảm bệnh điều trị theo đơn.

\section{BÀN LUÂ̂N}

Nhóm tuổi phổ biến nhất trong nghiên cứu của chúng tôi là từ 25 đến 29 tuổi với $58,8 \%$, tiếp đến là nhóm 30-34 tuổi với 18,8\%, nhóm < 25 tuổi có tỷ lệ là $16,2 \%$, thấp nhất là nhóm 35 đến 39 tuổi với 6,2\%. Tuổi trung bình của bệnh nhân trong nhóm nghiên cứu là 28,62 $\pm 3,49$ năm, bệnh nhân ít tuổi nhất là 20 tuổi, lớn nhất là 36 tuổi (bảng 3.1). Kết quả cho thấy tuổi trung bình tương đối trẻ, đi kèm với tuổi trẻ thường có dự trữ buồng trứng tốt hơn, có thể dẫn đến nguy cơ quá kích buồng trứng cao hơn khi kích thích buồng trứng. Kết quả của chúng tôi tương đương với các tác giả khác nghiên cứu trong cùng thời gian ở Việt Nam và trên thế giới. Theo Trân Thùy Anh (2017), tuổi trung bình nhóm bệnh nhân quá kích buồng trứng là $31,6 \pm$ 4,2 năm². Theo Hanh Sokanha (2017), nghiên cứu 74 bệnh nhân quá kích buồng trứng nặng tại bệnh viện Phụ Sản Trung Ương năm 2017, tuổi trung bình của bệnh nhân quá kích buồng trứng là $28,50 \pm 3,6$ năm $^{3}$. Theo Cao $Y$ và cộng sự (2021) nghiên cứu 2020 chu kỳ quá kích buồng trứng trong cùng khoảng thời gian 2018-2019 thấy rằng độ tuổi trung bình là $28,44 \pm 3,69$ năm ${ }^{4}$. Theo Sun B và cộng sự (2021), nghiên cứu 669 bệnh nhân quá kích buồng trứng tuổi trung bình là $28,6 \pm 3,59^{5}$.

Thời gian vô sinh phổ biến là nhóm bệnh nhân vô sinh $<5$ năm chiếm $76,2 \%$, có $23,8 \%$ bệnh nhân vô sinh $\geq 5$ năm. Thời gian vô sinh trung bình là $4,45 \pm 1,56$ năm, ngắn nhất là 1 năm, dài nhất là 7 năm (bảng 3.1). 
Đa số bệnh nhân có thời gian mong con là dưới 5 năm. Điều này cho thây với sự phát triển của khoa học kỹ thuật, truyền thông giáo dục sức khỏe, đặc biệt là sự phát triển của các trung tâm điều trị vô sinh, bệnh nhân dễ dàng tiếp cận hơn với các kỹ thuật và khám chữa bệnh sớm hơn.

Từ đó phát hiện nguyên nhân vô sinh sớm , được điều trị sớm hơn. Kết quả của chúng tôi tương tự các tác giả khác trong cùng khoảng thời gian nghiên cứu. Theo Trần Thùy Anh (2017) thời gian vô sinh dưới 5 năm chiếm $65,16 \%^{2}$. Theo Hanh Sokhanha (2017), thời gian vô sinh phổ biến là nhóm bệnh nhân vô sinh $<5$ năm chiếm $77 \%$, thời gian vô sinh trung bình là $4,01 \pm 1,24$ năm ${ }^{3}$.

Nghiên cứu 80 bệnh nhân quá kích buồng trứng nặng chúng tôi thấy, triệu chứng cơ năng của bệnh nhân khi nhập viện rất đa dạng và điển hình. Tỷ lệ bệnh nhân có triệu chứng đau bụng là $88,8 \%$, tỷ lệ bệnh nhân buồn nôn và nôn là $83,8 \%$, tỷ lệ bệnh nhân có khó thở là $75,0 \%$, tỷ lệ bệnh nhân có thiệu niệu là $41,2 \%$ (bảng 3.2). Không có bệnh nhẩn nào nhập viện trong tình trạng rất nặng với các biểu hiện của vô niệu, suy thận cấp, suy hô hấp. Kết quả của chúng tôi tương đương với những tác giả khác nghiên cứu về quá kích buồng trứng nặng khác. Theo Hanh Shokhanha (2017), nghiên cứu tại bệnh viện Phụ Sản Trung Ương thấy rằng, tỷ lệ bệnh nhân có triệu chứng đau bụng là $97,3 \%$, tỷ lệ bệnh nhân buồn nôn, nôn $87,8 \%$, tỷ lệ bệnh nhân khó thở $94,6 \%$, tỳ lệ bệnh nhân thiệu niệu $51,4 \%{ }^{3}$.

Bệnh nhân có hạ albumin huyêtt thanh khi nhập viện chiếm $82,5 \%$, trong đó thấp nhất là $21,0 \mathrm{~g} / \mathrm{l}$. Nồng độ albumin huyết thanh trung bình khi bệnh nhân nhập viện là $31,5 \pm 4,5 \mathrm{~g} / \mathrm{l}$. Bệnh nhân hạ protein huyết thanh toàn phần chiếm $63,8 \%$, trong đó thấp nhất là $51,0 \mathrm{~g} / \mathrm{l}$. Nồng độ protein huyết thanh trung bình khi nhập viện là $63,70 \pm 4,8 \mathrm{~g} / \mathrm{l}$ (bảng 3.2). Điều này phù hợp với tiêu chuẩn chẩn đoán quá kích buồng trứng nặng của ASRM (2016), khi có giảm protein máu là được xếp vào nhóm quá kích buồng trứng vừa, kết hợp các tiêu chuẩn cơ năng và sinh hóa khác thì chẩn đoán là quá kích buồng trứng năng. Theo ASRM (2016), khi hematocrit > 41\% được gọi là có cô đặc máu và được xếp vào nhóm quá kích buồng trứng vừa, khi xuất hiện thêm các triệu chứng cơ năng và thực thể khác thì xếp vào nhóm nặng ${ }^{6}$. Trong nghiên cứu của chúng tôi, tất cả các bệnh nhân đều xuất hiện tình trạng này, trong đó tỷ lệ bệnh nhân cô đặc máu là mức độ nặng (hematocrit > 50\%) là 13,8\% (bảng 3.2). Trong tiêu chuẩn Abraham
Golan (2010) thì mức độ nặng được chẩn đoán khi mức độ cô đặc máu xuất hiện với hematocrit $>45 \%{ }^{7}$.

Trong nghiên cứu của chúng tôi, có 24 bệnh nhân chỉ điều trị nội khoa đơn thuần chiếm $30 \%$ và 56 bệnh nhân chiếm $70 \%$ phải điêu trị kết hợp cả nội khoa và chọc dịch ổ bụng. Tất cả các bệnh nhẩn được chọc dịch qua đường bụng. Không có bệnh nhân nào phải dẫn lưu màng phổi màng tim hay phải điêu trị bằng phương pháp phẫu thuật nội soi (bảng 3.3). Phù hợp với khuyến cáo lâm sàng của ASRM (2016) về phòng và điều trị bệnh nhân quá kích buồng trứng ${ }^{6}$.

Kết quả của chúng tôi tương tự các tác giả khác đã nghiên cứu về vấn đề này. Theo Phạm Thị Phương Lan (2014), có $64,1 \%$ bệnh nhân chọc hút dịch kết hợp điêu trị nội khoa, có $30 \%$ trường hợp chỉ cần điều trị nội khoa đơn thuần bằng bù dịch, chống huyết khối, trong đó có 3 bệnh nhân chỉ bù dịch qua đường uống. Tuy nhiên, trong nghiên cứu này có 2 bệnh nhân phải điều trị ngoại khoa: một trường hợp mổ do xoắn buồng trứng và một trường hợp do chảy máu buồng trứng nặng ${ }^{1}$.

Có $53,8 \%$ bệnh nhân khỏi hoàn toàn khi xuất viện, $46,2 \%$ bệnh nhân ra viện thuyên giảm bệnh điêu trị theo đơn, không có trường hợp tử vong (bảng 3.3). Kết quả của chúng tôi tương đương với các tác giả khác nghiên cứu điều trị bệnh nhân quá kích buồng trứng trong giai đoạn 2017-2019. Theo Hanh Sokhanha (2017), có $59,5 \%$ bệnh nhân khỏi hoàn toàn khi xuất viện, tỷ lệ bệnh nhân thuyên giảm cho xuất viện điều trị theo đơn là $40,5 \%{ }^{3}$.

\section{KẾT LUÂN}

Có 70\% bệnh nhân phải điều trị kết hợp cả nội khoa và chọc dịch ổ bụng. Khổng có bênh nhân nào phải chọc dịch màng phổi. Bệnh nhân khỏi hoàn toàn khi xuất viện là $53,8 \%, 46,2 \%$ bệnh nhân ra viện thuyên giảm.

\section{TÀI LIẸU THAM KHẢO}

1. Phạm Thị Phương Lan. "Nghiên cứu các yễu tố ngưy cơ và xử trí quá kích buồng trứng ở các bệnh nhân IVF tại Bệnh viện Phụ sản Trung Ương". Luận văn thạc sĩ. 2013.

2. Trân Thùy Anh (2017). "Nghiên cứu một số yễu tố tiên lượng đáp ứng của buồng trứng trong thụ tinh trong ông nghiệm". Luận văn Tiên Sỹ Y Học. Đai Hoc Y Hà Nôi 2017, tr: 8

3. Hanh Sokanhà (2017) "Đánh giá kết quả điều trị hội chứng quá kích buồng trứng nặng sau thụ tinh trong ống nghiệm tại Bệnh viện Phụ Sản Trung ương" Luận văn thạc sĩ y học, Đại học Y Hà Nội, tr: 31-45

4. Cao Y, Shi H, Ma Y, Ma L and Zhai J (2021) 
Effect and Relationship ofSeasons on the High Risk of Ovarian Hyperstimulation Syndrome After Oocyte Retrieval in Patients With Polycystic Ovary Syndrome. Front. Endocrinol. 11:610828.

5. Sun B, Ma Y, Li L, et al (2021). Factors Associated with Ovarian Hyperstimulation Syndrome (OHSS) Severity in Women With Polycystic Ovary Syndrome Undergoing IVF/ICSI.
Front. Endocrinol. 11:615957.

6. Klaus Fiedler, Diego Ezcurra (2016). Prevention and treatment of moderate and severe ovarian hyperstimulation syndrome: a guideline. Fertil Steril, 2016;106:1634-1647.

7. Golan A, et al (2010), A modern classification of OHSS, Reproductive BioMedicine, Vol 19, No 1, pp: 28-32.

\title{
ỨNG DỤNG KỸ THUÂTT MULTIPLEX LIGATION-DEPENDENT PROBE AMPLIFICATION XÁC ĐİNH ĐộT BIẾN GEN $\alpha$ THALASSEMIA Ở BÊ̂NH NHÂN HBH
}

\author{
Lê Thanh Hằng*, Lê Thị Phương*, \\ Trần Huy Thịnh*, Trần Vân Khánh*
}

\section{TÓM TẮT}

Bệnh a-thalassemia thường là gây nên là do đôt biến xóa đoan gen HBA1 và HBA2 làm thiếu hut chuỗi a-globin cấu thành nên phân tử Hemoglobin. Tùy theo số lương chuỗi a bi thiếu hut mà mức độ biểu hiên lâm sàng của bệnh ở các cấp độ khác nhau. Xác định đôt biến gen trền bệnh nhân sễ giúp chẩn đoán xác định và tư vấn di truyền cho các thành viên gia đình bềnh nhân. Trong nghiên cứu này, kỹ thuât Multiplex Ligation-dependent Probe Amplification (MLPA) đã được áp dung để xác định đột biến trên 21 bệnh nhân mắc bệnh a-thalassemia dựa vào các chỉ số huyết học, điện di huyết sắc tố và các dấu hiệu lâm sàng. Nghiên cứu đã xác định được 14/21 bệnh nhân mang kiểu gen --SEA/-a3.7, 7/21 bệnh nhân mang kiểu gen -SEA/-a $a^{4.2}$. MLPA là kỹ thuật khá hiệu quả để phát hiện các đột biến mất đoạn trển bệnh a thalassemia ở Việt Nam.

Tư khóa: bênh a- thalassemia, HbH, MLPA, -SEA/-a ${ }^{3.7},--S E A /-a^{4.2}$.

\section{SUMMARY}

APPLYING MULTIPLEX LIGATION-

\section{DEPENDENT PROBE AMPLIFICATION \\ TECHNIQUE TO DETECT MUTATION IN ALPHA THALASSEMIA PATIENTS}

Alpha-thalassemia disease is mostly caused by mutations in the HBA1 and HBA2 genes that lead to the deficiency in the a-globin chain, which builds up the hemoglobin molecule. Depending on the number of missing a chains, the clinical manifestations of the disease are at different levels. Detecting mutations in patients will help diagnose and genetic counseling for the patient's family. Multiplex Ligation-dependent Probe Amplification (MLPA) technique was applied to

*Trường Đại học Y Hà Nội

Chịu trách nhiệm chính: Trần Vân Khánh

Email: tranvankhanh@hmu.edu.vn

Ngày nhận bài: 10.9.2021

Ngày phản biên khoa họ: 2.11.2021

Ngày duyệt bài: 12.11.2021 detect mutation of HBA1, HBA2 gene in DNA samples of 21 people suspected of having a-thalassemia, based on test results of red blood cells and hemoglobin, the study identified $14 / 21$ people carry the genotype -SEA/- $a^{3.7}, 7 / 21$ people carry the genotype --SEA/-a ${ }^{4.2}$ MLPA is effective method to detect the deletion and duplication mutation in Vietnam a-thalassemia patients.

Keywords: a- thalassemia disease, $\mathrm{HbH}, \mathrm{MLPA},-$ SEA/-a $a^{3.7},--S E A /-a^{4.2}$

\section{I. ĐĂT VẤN ĐỀ}

Bệnh a-thalassemia là bệnh di truyên lặn trên nhiễm sắc thể thường, đặc trưng bởi sự suy giảm hoặc thiếu hụt tổng hợp chuỗi a globin trong phân tử Hemoglobin. Bênh thuộc nhóm bệnh di truyền phổ biến nhất, là nguyên nhân gấy thiếu máu tan máu hàng đầu ở trẻ em.1 Bệnh a-thalassemia xuất hiện ở tất cả các chủng tộc trên thế giới, rất phổ biến ở các nước Đông Nam Á. Hiện có khoảng $5 \%$ dân số thế giới là người mang gen bệnh a-thalassemia, bao gồm dạng a+ -thalassemia, a0 -thalassemia, phân bố khác nhau ở từng khu vực, quốc gia, chủng tộc khác nhau. Tại Trung Quốc, người mang gen athalassemia chiếm $5-15 \%$ dân số, Thailand 15$30 \%$, Lào $43 \%$, và Việt Nam có $45 \%$ dân số mang gen bệnh. 2

Ở người bình thường, trên mỗi NST số 16 có hai gen a globin, và có tổng cộng bốn gen a globin trên hai NST 16 tương đồng (aa/aa).3,4 Tùy theo số lượng gen a bi đột biến, và tùy theo sự kết hợp đa dạng giữa các dạng alen đột biến khác nhau của bệnh a-thalassemia, gây ra các biểu hiện lâm sàng ở nhiều mức độ khác nhau. a thalassemia cũng được phân loại dưa trên số lượng alen bi đột biến; đột biến xuất hiện ở 1 aleen được gọi là $a+$ thalassemia (hay còn gọi là thalassemia thể ẩn); đột biến xuất hiện ở 2 alen ta có thể a0 thalassemia. Bênh a thalassemia 